\title{
HOW THE TYPE OF OWNERSHIP AFFECTS CAPITAL BUDGETING PRACTICE IN THE SERBIAN AGRIBUSINESS INDUSTRY?
}

\author{
Lidija Barjaktarović ${ }^{1}$, Renata Pindžo ${ }^{2}$, Snežana Konjikušić ${ }^{3}$ \\ *Corresponding author E-mail: lbarjaktarovic@singidunum.ac.rs
}

\begin{abstract}
A R T I C LE I N F O
A B S T R A C T

Original Article

Received: 21 September 2020

Accepted: 20 November 2020

doi:10.5937/ekoPolj2004141B

UDC 332.852:330.1]:[330.562: 338.43(497.11)

The subject of the research is capital budgeting practices in Serbian agribusiness companies. The research aim is to determine whether there are differences in decision-making regarding capital budgeting depending on the ownership structure in those industries. The research was conducted in the first half of 2019, on a sample of 76 companies (from 122 targeted/i.e. $62.33 \%$ respondent rate) operating in the Republic of Serbia. Descriptive statistics and the Kruskal-

\section{Keywords:}

capital budgeting, CEO, CFO, ownership structure, treasury, and enterprise risk management

JEL: G30, G31, G32, G35

Wallis test were used in the data analysis. IBM SPSS 20.0 statistical package was used for data processing. Research results confirmed that capital budgeting practices in the Serbian agribusiness companies can be considered as developed. Furthermore, there is a difference in the capital budgeting practices in the Republic of Serbia depending on the ownership of the analyzed sampled companies.
\end{abstract}

(C) 2020 EA. All rights reserved.

\section{Introduction}

Capital budgeting /CB/ is a basic decision in business finance (Brealy et al. 2007). A company decides to which (real) assets should be acquired, and it determines future business and benefits (Brealy et al. 2007). Furthermore, it is the most important when it comes to the creation of value /from investment/ (Van Horne, J., \& Wachowicz, J, 2007). Accordingly, to Bodie et al. (2008), investment is the current commitment of money or other resources in the expectation of reaping future benefits. Finally, Palepu et al. (2007) emphasized that expected earnings and Return on Equity are crucial for investments.

1 Lidija Barjaktarović, Full-professor, Singidunum University Belgrade, Danijelova 32, 11000 Belgrade, Phone: + 381653093 238, E-mail: lbarjaktarovic@singidunum.ac.rs, ORCID ID (https://orcid.org/0000-0002-5630-8595)

2 Renata Pindžo, Associate Professor, University Metropolitan, FEFA Faculty, Zorana Đinđića No. 44, 11070 New Belgrade/ Ministry of Trade, Tourism and Telecommunications, Nemanjina 22-26; Phone: +381 113122 855, E-mail: renata.pindzo@mtt.gov.rs, ORCID ID (https://orcid.org/0000-0002-1027-0827)

3 Snežana Konjikušić, Associate Professor, University Metropolitan, FEFA Faculty, Zorana Đinđića No. 44, 11070 New Belgrade, Phone: +381 6947776 05, E-mail: skonjikusic@ fefa.edu.rs, ORCID ID (https://orcid.org/0000-0002-8899-2133) 
Having in mind the importance of the topic for the company's management, different authors carry out research based on the CB practice all over the world: 1. Australia: Truong et al., 2008; 2. USA: Gitman \& Forrester, 1977; and Graham, Harvey, 2001; 3. Canada: Vijay \& Ashwani, 1995; and Graham, Harvey, 2001; 3. European countries and regions: Brounen et al. 2004; Haas \& Peeters, 2006; Dedi \& Orsag, 2007; Sandahl \& Sjögren, 2003; Hermes \& Smid, 2007; Andor et al. 2011; Daunfeldt, S. \& Hartwig, F, 2011; Orsag, S. \& Mitar, J. 2014; Dragota et al. 2011; Wnuk-Pel, T, 2014; Barjaktarovic et al. 2015, Barjaktarović et al. 2016; Petković et al. 2019; and Stoimenova, E., 2019; 4. Asia: Kester et al. 1999; and Batra \& Verma, 2017; 5. Africa: Correia, C, 2012; and Hall, J. \& Millard, S, 2011. The main conclusion is that the level of development of the country has an influence on applied CB practices i.e. higher level of economic development - more sophisticated CB practice.

The digital transformation of enterprises on an intelligent way (Schliebs, 2018) requires more analytical skills from CFOs in all industries. Moreover, 63\% of CEO (Chief Executive Officer) see Fourth Industrial Revolution (technologies - digital, physical, and biological) as a critical accelerator of the socio-economic impact of their companies. Moreover, it goes in line with the EU Strategic Plan 2020, to connect the digital single market (European Commission, 2016). It is following Think 2030, i.e. agribusiness sector in the EU and its potential to provide services to society is starkly contrasted by the impact that many current agricultural practices have on the environment, health, and climate, as well as on the long-term resilience and competitiveness of the sector itself (Allen et al. 2018). It is important to stress that agribusiness in Europe is under the increasing pressure of globalization, which is moving toward production standardization based on economic competitiveness (Chmieliński \& Soliwoda, 2016). Moreover, less developed countries share of agriculture and agribusiness in the national incomes is much higher than in the highly developed countries (Mrówczyńska-Kamińska \& Baer-Nawrocka, 2016). The Republic of Serbia, agribusiness has a great impact on GDP (gross domestic product) growth (Statistical Office of the Republic of Serbia, 2020). Furthermore, CEOs recognize a food innovation as a potential accelerator of global sustainability. Innovation will play a key role in the reengineering of the food system and they are ready for revolution "food-tech" that creates new opportunities for transformation across the food supply chain (UNGC, 2019). It can be concluded that companies should invest in order to obtain sustainable growths. It requires an adequate risk management approach which will take into consideration all theoretically possible scenarios for the business. Accordingly, the pandemic is one of them - COVID 19 influences companies' businesses. However, companies should continue with business processes and further development. Following it, $41 \%$ of CFOs plan to reduce their capital expenditures, twice as many as the $20 \%$ who plan to increase them (Deloitte, 2020).

The subject of the research is $\mathrm{CB}$ practices in the Serbian agribusiness companies (SAC). The aim of the research is to determine whether there are differences in decision-making (DM) regarding the $\mathrm{CB}$ depending on the ownership structure in those industries. Accordingly, the main hypothesis of the research (H0) is that there 
is a difference in the CB DM process in the SAC based on ownership structure (OS). Furthermore, the additional hypothesis of the research (H1) is: CB practices in the Serbian agribusinesses companies can be considered as developed based on OS.

Recognizing the subject and purpose of research, this paper is conceived in four parts. The introduction defines the subject, aim and expected contributions to the research. The second part will be presented applied methodology. The third part of the paper will be discussed with research results. The research will be completed with concluding remarks.

\section{Methodology}

For the research, authors created questionnaire with 17 questions, divided into the two groups: I - personal data and II - CB. The questionnaire was sent via e-mail to financial departments of 122 companies (in targeted sectors) in the first half of 2019.

Furthermore, 76 companies returned fulfilled questionnaire, which represents $62.3 \%$ respondent rate and obtained results can be consider valid for future conclusions. The basic criterion for forming the sample were OS and sectors belonging. The OS of the sample is: 26 foreign-owned /FO/ (36.84\%), 23 domestic privately-owned / $\mathrm{DPO} /(30.26 \%)$ and $25 \mathrm{mixed} / \mathrm{MO}$ - state owned; joint owned. i.e. state and private owned; cooperatives; institutes; agencies/ (32.89\%). The sample consists of 13 sectors related to agribusiness companies: production and distribution of agricultural products $(28.95 \%)$; production of water, non-alcoholic and energy drinks /beverage industry/ (13.16\%); two equal groups of respondents (10.53\% each) are in production of: 1) confectionery products and 2) bread, dough, flour; dairy production and cheese processing (7.89\%); sugar production (6.58\%); animal feed production (5.26\%); production of beer, wine, brandy (3.95\%); three equal groups of respondents $(2.63 \%$ each) are in:1) coffee production and distribution, 2) organic food production and 3) meet production; production of edible oils; two equal groups of respondents $(1.32 \%$ each) are in: 1) tobacco production and distribution, and 2) agro pellet production.

The structure of the sample with regard to the position of respondents is: CEO (37.66\%); CFO (33.77\%); financial analysts (7.79\%); two equal groups of respondents $(3.90 \%$ each) are financial managers and financial consultants; treasury and risk manager (5.19\%); and three equal groups $(2.60 \%$ each) are financial controllers, collection managers and associate for financial planning. The gender structure of the respondents' sample is $55.26 \%$ male, and $44.74 \%$ female. The educational structure of the respondents' sample is $6.58 \%$ Ph.D. 9.21\% master of business administration, $81.58 \%$, Bachler of business administration, and $2.63 \%$ bachelor of college. The average age of the respondents is 47 , while the average years on the position is 11 .

Out of 17 questions, 9 questions are related to $\mathrm{CB}$ applied 5-point scale i.e. from 1 to 5 (where it means: 1-never, 2-very-rare, 3-sometimes, 4-often, and 5-always). The first question is related to the clearly defined investment and development policy. The second issue deals with the business plan (BP) as one of the instruments of investment planning in the future. The third question considers whether the company makes a cash flow (CF) 
projection before making an investment decision. The analysis of investment criteria/IC/ (net present value (NPV), internal rate of return (IRR), profitability index (PI), payback criterion $/ \mathrm{PB} /$, accounting rate of return (ARR), discounted payback criterion /DPB/, sensitivity analysis (SA) and other $(\mathrm{O})$ ) used in the company when selecting a project is discussed in the fourth question. As part of the fifth question, the method of calculating the cost of capital when making an investment decision was examined using: CAPM (Capital Asset Pricing Model), average historical returns on common shares /AHRCS/, average historical returns on previous investments /AHRPI/, discounted dividends model /DDM/, rates assigned by the state /RAS/ and other/O/. The sixth and seventh questions are discussed in an investment DM process whether the discount rate (DR) and/or CF are adjusted for the following risk factors: changes in market interest rates (MIR), foreign exchange (FX) risk, business risk (BR), inflation, and changes in raw material prices (RMP). The next question analysed whether a company makes a difference between the company's and the risk related to a particular investment when determining the DR. Finally, the last question explores the most common type of investment a company has had in the last 12 months. The offered investments are: an investment in production, new facilities and opening of new factories; introduction of a new product; design change of the existing product; market expansion; investing in staff, etc.

Descriptive statistics and the Kruskal-Wallis test were used in the data analysis. IBM SPSS 20.0 statistical package was used for data processing.

\section{Research Results}

It can be noticed in the sector related to agribusiness that relevant facts for $\mathrm{CB}$ decision process making are: 1) CEO has significant influence, 2) male participation is dominant, 3 ) high education is required, and 4) above 10-years' experience is needed. Furthermore, regarding the origin of equity in the analysed companies, it can be observed that the enlargement process is present, and investors from other sectors start activities through acquisition or as green-field investments. It can be explained by the fact that those sectors need huge investments with slowly returning on investment. Finally, obtained results can be compared with other researches findings conducted in the Republic of Serbia (Petković et. al, 2019; Barjaktarović et.al, 2016; Barjaktarović et.al, 2015) due to the similar structure of the part of the questionnaire connected to CB.

Clearly defined investment and development policy as a component of the concept of CB, in the considered companies is mostly rated with often $(56.8 \%)$ and always $(43.42 \%)$. If we look at the definition of investment and development policy concerning the OS of the company, the results are shown in Table 1. Those results are in line with research findings of Petković et al. (2019) and Barjaktarović et al. (2015). It can be noticed that all MO answered often, while majority FO and DPO said always. It is interesting to observe that in the case of findings of Petković et al. (2019) where FO companies attach the highest importance to the clearly defined investment and development policy, findings of this research can be explained with the fact that in analysed agribusiness companies are big local (DPO) companies (that perform businesses in the country and abroad) which can 
be defined as group of connected companies /GCC/ (Barjaktarović et al. 2016a) which implemented adequate enterprise risk management (ERM) concepts and treasury.

Table 1. Appliance of clear investment and development policy in CB process in the company

\begin{tabular}{|c|c|c|}
\hline OS & Often & Always \\
\hline FO & 9 & 19 \\
\hline DPO & 9 & 14 \\
\hline MO & 25 & \\
\hline Total & $\mathbf{4 3}$ & $\mathbf{3 3}$ \\
\hline
\end{tabular}

Source: Authors' calculations

The BP as one of the planning instruments where the investment plan for the future period is stated in detail, as well as the CF projection before making the investment decision, are always used in all analyzed companies, regardless of their OS. The result of the research concerning the BP in relation to the OS is given in the Table 2.

Table 2. Appliance of BP in investment planning

\begin{tabular}{|c|c|c|c|}
\hline OS & Never & Sometimes & Always \\
\hline FO & & & 28 \\
\hline DPO & & 2 & 21 \\
\hline MO & 1 & & 24 \\
\hline Total & $\mathbf{1}$ & $\mathbf{2}$ & $\mathbf{7 3}$ \\
\hline
\end{tabular}

Source: Authors' calculations

CF projections before making an investment decision, without distinction, are often used in all analysed companies, regardless of their OS. It is important to emphasize that the BP and CF projections before making the investment decision are always used in analysed companies, regardless of their OS, and it is in line with the research findings of Petković et al. (2019). Specifically, 48 of the 76 companies always deal with CF projections before making an investment decision, 27 of the 76 analysed often deal with the question asked and only one company deals with the question asked very rarely. Table 3 contains the results of research on attitudes towards CF depending on the type of OS. It can be noticed that all FO answered always and all MO said often. The majority of DPO answered always, while the minority said often or very-rare, which can be explained with the size of the company and implemented ERM procedures and treasury (Jelenković \& Barjaktarović, 2016; Barjaktarović \& Vićentijević, 2017).

Table 3. Appliance of CF projections before making an investment decision

\begin{tabular}{|c|c|c|c|}
\hline OS & Very-rare & Often & Always \\
\hline FO & & & 28 \\
\hline DPO & 1 & 2 & 20 \\
\hline MO & & 25 & \\
\hline Total & $\mathbf{1}$ & $\mathbf{2 7}$ & $\mathbf{4 8}$ \\
\hline
\end{tabular}

Source: Authors' calculations 
When selecting a project, the analysed companies the most often apply the following IC: NPV, IRR, PI, PB, ARR, DPB, SA, and O (Table 4). On the basis of given answers, it couldn't make the appropriate conclusion about the most often used IC in the sample. It can be explained with the characteristics of businesses of analysed companies and skills of sampled companies' staff involved in the investment decision process. These responses showed some deviation from previous studies, where PB was the predominantly used IC (Petković et al. 2019; Barjaktarović et al. 2016; Barjaktarović et al. 2015).

Table 4. Appliance of IC in project selection

\begin{tabular}{|c|c|c|c|c|c|c|}
\hline The IC & Never & Very rare & Sometimes & Often & Always & $\begin{array}{c}\text { To no of } \\
\text { answers }\end{array}$ \\
\hline NPV & 1 & 1 & 14 & 27 & 27 & $\mathbf{7 0}$ \\
\hline IRR & 2 & & 41 & 3 & 17 & $\mathbf{6 3}$ \\
\hline PI & & 1 & 47 & 4 & 13 & $\mathbf{6 5}$ \\
\hline PB & 1 & 1 & 29 & 9 & 30 & $\mathbf{7 0}$ \\
\hline ARR & 2 & 1 & 15 & 25 & 9 & $\mathbf{5 2}$ \\
\hline DPB & 1 & & 50 & 1 & 8 & $\mathbf{6 0}$ \\
\hline SA & & 35 & 15 & 1 & 15 & $\mathbf{6 6}$ \\
\hline O & & 24 & 3 & & 1 & $\mathbf{2 8}$ \\
\hline
\end{tabular}

Source: Authors' calculations

To determine whether companies with different OS use the same or different IC when selecting a project, the Kruskal-Wallis test was used. This test showed a statistically significant difference in the use of the above IC for companies of different OS (FO: $\mathrm{n}=$ 28, $\mathrm{Md}=49.75 ; \mathrm{DPO}: \mathrm{n}=23, \mathrm{Md}=45.96 ; \mathrm{MO}: \mathrm{n}=25, \mathrm{Md}=19.04) \chi 2(2.76)=31.229$, $\mathrm{p}$-value $=0.000$. The test results show that MO pays significantly less attention to IC compared to companies with FO and DPO. It can be explained by the fact that ERM is better developed and implemented in FO and DPO (Barjaktarović \& Vićentijević, 2017). Furthermore, those companies have separately organized treasury departments within the finance division and they took part in this research. It is in line with the research findings of Jelenković \& Barjaktarović (2016).

When making an investment decision, the cost of capital is calculated by applying: CAPM model, AHRCS, AHRPI, DDM, RAS, and O. The survey results for all companies are presented in the given Table 5 and they can be explained with the same argumentation which is given for previous two questions. Those are the reasons why the research findings are not in line with the results of Petković et al. (2019), Barjaktarović et al. (2016), and Barjaktarović et al. (2015). 
Table 5. Appliance of the method in calculating the cost of capital in making investment decision

\begin{tabular}{|c|c|c|c|c|c|c|}
\hline The method & Never & Very-rare & Sometimes & Often & Always & $\begin{array}{c}\text { To no of } \\
\text { answers }\end{array}$ \\
\hline CAPM & 2 & 25 & 6 & 9 & 11 & $\mathbf{5 3}$ \\
\hline AHRCS & 27 & 9 & 14 & 1 & & $\mathbf{5 1}$ \\
\hline AHRPI & & 1 & 46 & 14 & 1 & $\mathbf{6 2}$ \\
\hline DDM & 34 & 15 & & 1 & & $\mathbf{5 0}$ \\
\hline RAS & 26 & 14 & 9 & 8 & & $\mathbf{5 7}$ \\
\hline O & 1 & 2 & 3 & 6 & 1 & $\mathbf{2}$ \\
\hline
\end{tabular}

Source: Authors' calculations

Similar to the previous question, the Kruskal-Wallis test indicates the existence of a significant difference in the calculating of cost of capital when making an investment decision in relation to the OS of the company. The test results show: $\mathrm{Md}=47.6$ for 24 $\mathrm{FO}$, for $20 \mathrm{DPO}, \mathrm{Md}=45.18$ and for $24 \mathrm{MO} \mathrm{Md}=12.5$, as well as $\chi 2(2,68)=49,008$, $\mathrm{p}$-value $=0.000$. The issue is mostly addressed by FO, to a lesser extent by DPO, while companies with MO do not pay significant attention to this issue.

When making an investment decision, the DR is adjusted for the following risk factors in order: FX risk, inflation, and change of RMP, BR, and change of MIR (Table 6). It is logical, having in mind the characteristics of the DR for agribusiness. It is the reason why the research findings are different from the findings of Petković et al. (2019). FX risk is the most important factor for adjusting the DR, due to the fact that companies import raw-materials and export final products /according to Jeremić et al. (2016) food-processing industry is large exporters that provide huge net value for country's economy/ in convertible currencies. Moreover, they use different trade finance products and derivate arranged with FX clause or FX. Secondly, inflation is a relevant factor for all business arrangements in dinars. Thirdly, the change of RMP is especially important in terms of commodities subject of trade on the international market and state's decision on excise or subsidized goods. Fourthly, BR has an influence on terms and conditions which will be agreed with creditors, suppliers and customers. Finally, the change of MIR will have influence on all business activities and arrangements of the company.

Table 6. Appliance of risk factors in adjusting a discount rate in the investment decision process

\begin{tabular}{|l|l|l|l|l|l|l|}
\hline Risk factors & Never & Very-rare & Sometimes & Often & Always & To no of answers \\
\hline FX risk & & & 10 & 32 & 28 & 70 \\
\hline Inflation & & & 12 & 38 & 19 & 69 \\
\hline Change of RMP & & 2 & 33 & 9 & 24 & 68 \\
\hline BR & & 1 & 35 & 9 & 22 & 67 \\
\hline Change of MIR & 1 & & 35 & 7 & 23 & 66 \\
\hline
\end{tabular}

Source: Authors' calculations 
It is evident that this question is mostly dealt with by all companies, because very few answers are never and very-rarely. The analysis of this issue considered for companies divided into three groups concerning the OS indicates the existence of a statistically significant difference $(\chi 2(2,75)=22,958, \mathrm{p}$-value $=0,000)$. More precisely, the results of the Kruskal-Wallis test show that DPO give convincingly the greatest importance to this issue $(\mathrm{n}=23, \mathrm{Md}=53.35)$, followed by FO give much less importance $(\mathrm{n}=28, \mathrm{Md}$ $=37.82)$, and finally the company with $\mathrm{MO}(\mathrm{n}=24, \mathrm{Md}=23.5)$.

When making an investment decision, CF are adjusted for the following risk factors in order: FX risk, change of RMP, inflation, change of MIR, and BR. It can be explained with the essence of CF in agribusiness. It is the reason why the research findings are different from the findings of Petković et al. (2019). FX risk is the most important factor for adjusting the $\mathrm{CF}$, having in mind that official reports are preparing in dinars, and in-coming and out-coming payments can be in different convertible currencies. Secondly, the change of RMP is especially important in terms of local and global influence on daily cash circulation. Thirdly, inflation is a relevant factor for all business arrangements in dinars and generated cash. Fourthly, change of MIR will have an influence on all business activities and arrangements of the company expressed in incoming and outgoing payments. Finally, BR has influence on terms and conditions which will be agreed with stakeholders and accordingly cash flow circulation. The results of the research on this question (Table 7), show that the answers to various risks are mostly: sometimes, often, and always.

Table 7. Appliance of risk factors in adjusting a cash flow in the investment decision process

\begin{tabular}{|l|c|c|c|c|c|c|}
\hline Risk factors & Never & Very-rare & Sometimes & Often & Always & To no of answers \\
\hline FX risk & & & 10 & 32 & 28 & $\mathbf{7 0}$ \\
\hline $\begin{array}{l}\text { Change of } \\
\text { RMP }\end{array}$ & 1 & 1 & 9 & 32 & 27 & 70 \\
\hline Inflation & & 1 & 10 & 34 & 23 & $\mathbf{6 8}$ \\
\hline $\begin{array}{l}\text { Change of } \\
\text { MIR }\end{array}$ & & 1 & 10 & 34 & 23 & $\mathbf{6 8}$ \\
\hline BR & & 2 & 42 & 1 & 22 & $\mathbf{6 7}$ \\
\hline
\end{tabular}

Source: Authors' calculations

If the mentioned question is analyzed from the angle of companies of different OS, the results of the Kruskal-Wallis test are similar to the previous question. Namely, the test indicates the existence of a statistically significant difference $(\chi 2(2,75)=22,701$, $\mathrm{p}$-value $=0,000)$ between FO, DPO, and Mo in relation to this issue. As the test results showed that: $\mathrm{Md}=52.85$ for $23 \mathrm{DPO}, \mathrm{Md}=38.23$ for $28 \mathrm{FO}$, and $\mathrm{Md}=23.50$ for 24 $\mathrm{MO}$, it is clear that DPO pays the most attention to this issue.

The results of the analysis of whether the company distinguishes between the company's risk and the risks related to a particular investment when determining the DR are presented in Table 8. It can be noticed that answers are mostly: very-rare, often and always. It is in line with the findings of Petković et al. (2019). The majority of 
respondents said often, where all MO stressed it. The second large group of respondents answered always, and the majority DPO confirmed it. The third important group said very-rare, where the majority came from FO. It is an interesting result, having in mind that FO companies usually have better ERM practices, and understands risks connected to their business and enterprises itself (Petković et al. 2019). Those results can be explained with the companies' staff sample and their skills. It can be concluded that there is a difference in making distinguishes between the company's risk and the risks related to particular investment when determining the DR regarding ownership structure: 1) DPO always, 2) MO often, and 3) FO very-rare.

Table 8. Distinguish between the company's risk and the risks related to a particular investment in the moment of determining the discount rate

\begin{tabular}{|c|c|c|c|c|}
\hline OS & Never & Very-rare & Often & Always \\
\hline FO & 1 & 11 & 9 & 7 \\
\hline DPO & & 1 & 6 & 15 \\
\hline MO & & & 24 & \\
\hline Total & 1 & 12 & 39 & 22 \\
\hline
\end{tabular}

Source: Authors' calculations

By analyzing the type of investment that the company had in the last 12 months, where the following investments were considered in order: introduction of a new product; design change of the existing product; market expansion; investing in staff; introduction of a new product; investment in production, new facilities and opening of new factories (Table 9). On the basis of given answers, it couldn't make the appropriate conclusion about the most important types of investments in the previous 12 months in the analysed sample of companies. Those findings are different comparing to Petković et al. (2019). It can be explained with the research results of UNGC (2019), where food innovation i.e. "food-tech" is a potential accelerator for transformation across the food supply chain.

Table 9. Type of investment in the previous 12 months

\begin{tabular}{|c|c|c|c|c|c|c|}
\hline Type of investment & Never & $\begin{array}{c}\text { Very- } \\
\text { rare }\end{array}$ & Sometimes & Often & Always & Total \\
\hline $\begin{array}{c}\text { Investment in production, } \\
\text { new facilities and opening of } \\
\text { new factories }\end{array}$ & 1 & 35 & 17 & 14 & $\mathbf{6 7}$ \\
\hline Introduction of a new product & & & & 16 & 24 & $\mathbf{4 0}$ \\
\hline $\begin{array}{c}\text { Design change of the existing } \\
\text { product }\end{array}$ & & 12 & 36 & 16 & $\mathbf{6 4}$ \\
\hline Market expansion & 7 & & 1 & 12 & 22 & $\mathbf{4 2}$ \\
\hline Investing in staff & & 2 & 26 & 9 & 30 & $\mathbf{6 7}$ \\
\hline Other & & & 1 & 4 & & $\mathbf{5}$ \\
\hline
\end{tabular}

Source: Author's calculations 
Dealing with the same issue, but in relation to the OS of companies, the KruskalWallis test recorded a significant statistical difference $(\chi 2(2,75)=43,469$, p-value $=0,000)$. The analysis included 76 companies, of which 28 were FO $(\mathrm{Md}=49.41), 23 \mathrm{DPO}(\mathrm{Md}=48.63)$ and $25 \mathrm{MO}(\mathrm{Md}=14.50)$. These results indicate that the difference is due to $\mathrm{MO}$ where this issue is quite neglected. Finally, when all questions on CB are summarized, the results of the Kruskal-Wallis test indicate the existence of a statistically significant difference between companies of different OS $(\chi 2(2,76)=43,804, p$-value $=0,000)$. There is an obvious difference between FO and DPO in relation to companies of MO. This analysis included: 28 FO where $\mathrm{Md}=48.29 ; 23 \mathrm{DPO}$ with $\mathrm{Md}=52.04$ and $25 \mathrm{MO}$ with $\mathrm{Md}=15.08$.

\section{Conclusion}

The key findings of the executed research are: 1) clearly defined investment and development policy as a component of the concept of $\mathrm{CB}$, in the considered companies is mostly rated with often and always. The majority of FO and DPO answered always. 2) The BP as one of the planning instruments where the investment plan for the future period is stated in detail, as well as the cash flow projection before making the investment decision, are always used in all analysed companies, regardless of their ownership structure. 3) When selecting a project, MO pays significantly less attention to IC compared to companies with FO and DPO. 4) When making an investment decision, the cost of capital is calculated by applying: CAPM model, AHRCS, AHRPI, DDM, RAS, and O. The issue is mostly addressed by FO, to a lesser extent by DPO, while companies with MO do not pay significant attention to this issue. 5) When making an investment decision, the DR is adjusted for the following risk factors in order: FX risk, inflation, and change of RMP, BR, and change of MIR. DPO gives convincingly the greatest importance to this issue followed by FO gives much less importance, and finally the company with MO. 6) When making an investment decision, CF are adjusted for the following risk factors in order: FX risk, change of RMP, inflation, change of MIR, and BR. DPO gives convincingly the greatest importance to this issue followed by FO gives much less importance, and finally the company with MO. 7) The results of the analysis of whether the company distinguishes between the company's risk and the risks related to a particular investment when determining the DR are DPO always, MO often, and FO very-rare. 8) By analysing the type of investment that the company had in the last 12 months, the results indicates that MO related this issue is quite neglected, comparing to FO and DPO.

Finally, when all questions on CB are summarized, the results of the Kruskal-Wallis test indicate the existence of a statistically significant difference between companies of different OS. There is an obvious difference between FO and DPO in relation to companies of MO. Those findings can be explained with the chosen sample of companies and their characteristics in terms of the business they perform, way of implementing ERM and treasury, and companies' staff involved in fulfilling the questionnaires. 
The research results confirmed the main hypotheses that there is a difference in the CB DM process in the SAC based on OS. Furthermore, it is confirmed that CB practices in the SAC can be considered as developed based on OS. Future research will go in the direction of establishing a link between companies that are groups of related parties in the country and abroad, in order to see if the same practice exists.

\section{Conflict of interests}

The authors declare no conflict of interest.

\section{References}

1. Allen, B, Bass-Deffosez, \& Weigelt, J. (2018). Feeding Europe: Agriculture and sustainable food systems, Institute European Environmental Policy \& Think Thank Sustainability

2. Andor, G., Mohanty, S., \& Toth, T. (2011). Capital budgeting practices: a survey of Central and Eastern European firms. The World Bank, January, 1 - 45.

3. Barjaktarović, L., \& Vićentijević, K. (2017). Analysis of the risk management practice in the Serbian companies, The book of proceedings FINIZ 2017: Challenges in modern corporate governance, Singidunum University Belgrade, 12/01/17, 1-7. DOI: 10.15308/finiz-2017-1-7

4. Barjaktarović, L., Djulić, K.,Pindžo, R.,\& Vjetrov, A. (2016). Analysis of the Capital Budgeting Practices: Serbian Case Management 79/2016, 47-54. DOI: 10.7595/management.fon.2016.0009

5. Jelenković, Z., \& Barjaktarović, L. (2016). The Risk Management Functions in the Conditions of Globalization: Case Study of the Republic of Serbia, Management 79/2016, 37 - 45. DOI: 10.7595/management.fon.2016.0010

6. Barjaktarović, L., Pindžo, R., \& Hanić, A. (2016a). Critical analysis of reliability of the model of investment credit approval in agriculture and food processing industry; The Balkan Scientific Association of Agrarian Economists, Belgrade, Institute of Agricultural Economics, Belgrade, Academy of Economic Studies, BucharestEconomics of Agriculture Vol LXIII, No3 (741-1112), 2016, Belgrade,751-766, UDC 330.322.2:631

7. Barjaktarović, L., Pindžo, R., Djulić, K., \& Vjetrov, A. (2015). The Analysis of Capital Budgeting Techniques Implemented by Small and Medium-Sized Enterprises in Serbia, The book of proceedings FINIZ 2015 - Contemporary Financial Management, 4-8. DOI: 10.15308/finiz-2015-4-8

8. Batra, R., \& Verma S. (2017). Capital budgeting practices in Indian companies, IIMB Management Review, 29/1, 29-44. DOI: doi.org/10.1016/j.iimb.2017.02.001

9. Bodie, Z., Kane, A., \& Marcus, A. (2008). Investments (10th Edition, ISBN 0077861671), McGraw-Hill/Irwin Series in Finance, Insurance and Real Estate, New York, USA 
10. Brealey, S., Mayers, S., \& Marcus, A. (2007). Principles of Corporate Finance (5th edition, ISBN 9780071105927). McGraw-Hill Company, New York, USA

11. Brounen, D., De Jong, A. \& Koedijk, K. (2004). Corporate Finance in Europe: Confronting Theory with Practice. Financial Management, 33, 71-101.

12. Chmieliński, P., \& Soliwoda, M. (2016). Models for competitive and sustainable and rural development in central eastern European countries, Rural areas and development, Vol.13

13. Correia, C. (2012). Capital budgeting practices in South Africa: A review, South African Journal of Business Management 43(2), 11-29. DOI:10.4102/SAJBM. V43I2.180

14. Dedi, L.,\& Orsag, S. (2007).Capital Budgeting Practices: A Survey of Croatian Firms. South East European Journal of Economics and Business, 2(1), 59-67. DOI: 10.2478/v10033-007-0016-y

15. Daunfeldt, S. \& Hartwig, F. (2011). What Determines the Use of Capital Budgeting Methods? Evidence from Swedish Listed Companies. Social Science Research Network, 1-37. DOI: 10.12691/jfe-2-4-1

16. Deloitte (2020) European CFO survey - a perspective on COVID -19

17. Dragota, I., Dragota, V., Tatu, L., Pele, D., \& Semenescu, A. (2011). Capital Budgeting: The Romanian credit analysists' points of view. The Review of Finance and Banking, 3(1), 39-45.

18. European Commission (2016). Strategic Plan 2016-2020, Directorate-General for Agriculture and Rural Development

19. Gitman, L.J. \& Forrester Jr. (1977). A survey of capital budgeting techniques used by major US firms. Financial Management, 6(3), 66-71. DOI: doi. org/10.2307/3665258

20. Graham J. \& Harvey C. (2001). The theory and practice of corporate finance: evidence from the field. Journal of Financial Economics, 60,187-243. DOI: 10.2139/ssrn. 220251

21. Haas R., \& Peeters M. (2006). The dynamic adjustment towards target capital structures of firms in transition economies. Economics of Transition. 14 (1), 133169. DOI: doi.org/10.1111/j.1468-0351.2006.00237.x

22. Hall, J., \& Millard, S. (2011). Capital budgeting practices used by selected listed South African firms, South African Journal of Economic and Management, 13(1), DOI: 10.4102/sajems. v13i1.200

23. Hermes, N.P. \& Smid, L.Y. (2007). Capital Budgeting Practices: a Comparative Study of the Netherlands and China. International Business Review, 16, 630-654. DOI:10.1016/J.IBUSREV.2007.05.002 
24. Jeremić, Z., Milojević, \& M., Terzić, I. (2016). Business performance of 15 largest exporters in food-processing industry in the period 2008-2014, The Balkan Scientific Association of Agrarian Economists, Belgrade, Institute of Agricultural Economics, Belgrade, Academy of Economic Studies, Bucharest- Economics of Agriculture Vol LXIII, No3 (741-1112), 2016, Belgrade, 943-957, UDC: 338.439 .02

25. Kester, G., Chang, R., Echanis, E., Haikal, S., Isa, M., Skully, M., Kai-Chong, T. \& Chi-Jeng, W. (1999). Capital Budgeting Practices in the Asia-Pacific Region: Australia, Hong Kong, Indonesia, Malaysia, Philippines, and Singapore. Financial Practice and Education, 9, 25-33.

26. Mrówczyńska-Kamińska, A., \& Baer-Nawrocka, A. (2016). The Significance of Agribusiness in the National Economy in the EU Countries, chapter in the monography: Chmieliński, P., Soliwoda, M. (2016) Models for competitive and sustainable and rural development in central eastern European countries, Rural areas and development, Vol.13

27. Orsag, S., \& Mitar, J. (2014). Application of cost of capital for capital structuring in Croatian firms. UTMS Journal of Economics. 5(2), 151-158.

28. Palepu, K., Healy, P., \& Bernard, V. (2007). Business Analysis \& Valuation Using Financial Statements (2nd edition), Tomson South-Western, New York, USA

29. Petković, G., Konjikušić, S., Barjaktarović, L., Pindžo, R. (2019). What is the Real State of Financial Management in Companies in the Republic of Serbia? Management: Journal of Sustainable Business and Management Solutions in Emerging Economies, 24 (2), 23-34, DOI: 10.7595/management.fon.2018.0002

30. Sandahl, G., \& Sjögren, S. (2003). Capital Budgeting Methods among Sweden's Largest Groups of Companies. The State of the Art and Comparison with Earlier Studies. International Journal of Production Economics, 84, 51-69. DOI: 10.1016/ S0925-5273(02)00379-1

31. Schliebs, H. (2018). CFO Priorities: Experts Predict Top Trends, Digitalist Magazine

32. Statistical Office of the Republic of Serbia (2020). Announcement indices of industrial production, June 2020, Press release

33. Stoimenova, E. (2019). The use of capital budgeting practices in Macedonian companies, master thesis, The faculty of economics, University Ljubljana

34. Truong, G., Partington, G. \& Peat, M. (2008). Cost-of-Capital Estimation and Capital-Budgeting Practice in Australia. Australian Journal of Management, 33, 95-121. DOI: doi.org/10.1177/031289620803300106

35. Van Horne, J.,\& Wachowicz, J.M. (2007). Osnovi finansijskog menadžmenta. Data status: Beograd

36. Vijay, J., \& Ashwani, K. (1995). Capital Budgeting Practices in Corporate Canada. Financial Practice and Education, 5(2), 37-43. 
37. United Nations Global Compact/UNGC/ - Accenture Strategy (2019). The decade to deliver a call to business action, CEO study on sustainability 2019

38. Wnuk-Pel, T. (2014). The practice and factors determining the selection of capital budgeting methods - evidence from the field, 19th International Scientific Conference; Economics and Management 2014, ICEM 2014, 23-25 April 2014, Riga, Latvia, 612-616. DOI: 10.1016/j.sbspro.2014.11.250. 